\title{
Energy efficiency of a hydrostatic drive with proportional control compared with volumetric control
}

\author{
Grzegorz Skorek, Ph.D. \\ Gdynia Maritime University, Poland
}

\begin{abstract}

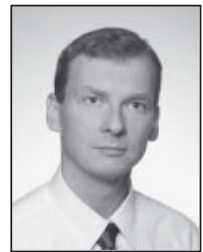

There are uninvestigated areas connected with behaviour of elements in hydraulic systems with different structures. Unawareness of proportions of the energy, volumetric, pressure and mechanical losses in elements is often the case. Problems connected with energy efficiency are essential for improvement of functionality and quality of hydrostatic drive systems, characterised by unquestioned advantages but also by relatively low efficiency in comparison with other types of drive. Energy efficiency of hydrostatic transmissions, particularly those with throttling control of the motor speed, and also efficiency of the hydraulic servo-mechanism systems may be in fact higher than the values most often quoted in publications on the subject. Possibility of calculating the real value of the hydraulic system overall efficiency as a function of many parameters influencing it, becomes a tool of complete evaluation of the designed system quality. The paper compares efficiencies of systems with cylinder proportional control and efficiency of the system volumetric control by a variable capacity pump. Presented are also two schematic diagrams of the investigated hydrostatic systems, their principle of operation and problems of studying losses in elements and energy efficiency of systems consisting of a feed assembly, control set and cylinder.
\end{abstract}

Key words: hydrostatic system; control structures; proportional directional valve; cylinder; energy losses; energy efficiency

\section{INTRODUCTION}

In searching for the energy saving solutions, computer-aided methods of calculating the energy efficiency of systems have been developed and improved.

The hydrostatic systems play a very important role in modern machines. Great number of the nowaday constructed machines have more or less developed hydrostatic or electrichydrostatic drive systems and in many cases those systems are the most important parts of the machines. Component elements - hydraulic linear motors (cylinders) - are widely applied in machines used on land and aboard ships. Unquestioned advantages of cylinders are: capability of performing the translational motion, reliability, simple construction, the effective force to weight ratio.

The required speed $\mathrm{v}_{\mathrm{M}}$ and load $\mathrm{F}_{\mathrm{M}}$ of the driven machine are a result of its operation cycle and tasks to be performed. The driven machine current speed and load values are independent of the type and structure of the machine driving system.

The current speed and load of the hydrostatic system driven machine have a direct or indirect impact on the mechanical, volumetric and pressure losses in the hydraulic motor, pump and other elements of the system with a given motor speed control structure, the losses resulting also from the hydraulic oil viscosity.
If, as an effect of the increasing, required by the driven machine, hydraulic motor operating speed $\mathrm{v}_{\mathrm{M}}$ or increasing, required by the machine, motor load $\mathrm{F}_{\mathrm{M}}$, and also as an effect of the mechanical, volumetric and pressure losses in the hydrostatic driving system elements, the maximum driving system capability, determined by the maximum pump capacity $\mathrm{Q}_{\mathrm{P} \max }$ or maximum pressure $\mathrm{p}_{\mathrm{P} 2 \max }$ in the pump discharge conduit limited to the system nominal pressure $p_{n}$, is used up, then

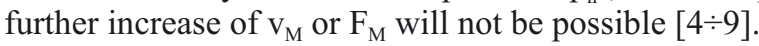

The maximum pump capacity $\mathrm{Q}_{\mathrm{P} \max }$ is less than its theoretical capacity $\mathrm{Q}_{\mathrm{Pt}}$. The pump theoretical capacity $\mathrm{Q}_{\mathrm{Pt}}$ is a product of the theoretical capacity $\mathrm{q}_{\mathrm{Pt}}$ per one pump shaft revolution and the no-load pump shaft speed $n_{\mathrm{P} 0}$. The pump $\mathrm{Q}_{\mathrm{Pmax}}$ capacity results from the loaded pump speed $\mathrm{n}_{\mathrm{P}}$, lower than the $\mathrm{n}_{\mathrm{P} 0}$ speed. At the same time, volumetric losses occur in the pump $[4 \div 9]$.

The system nominal pressure $\mathrm{p}_{\mathrm{n}}$ is a maximum permissible pressure $\mathrm{p}_{\mathrm{P} 2 \max }$ for its continuous operation, determined in the pump discharge conduit.

Maximum values of the hydrostatic drive system hydraulic motor speed $\mathrm{v}_{\mathrm{Mmax}}$ and load $\mathrm{F}_{\mathrm{Mmax}}$ are limited by the maximum pump capacity $\mathrm{Q}_{\mathrm{Pmax}}$ and the system (pump) nominal pressure $\mathrm{p}_{\mathrm{n}}$, and also by the mechanical, volumetric and pressure losses in other system elements, which are also an effect of the working liquid viscosity $[4 \div 9]$. 


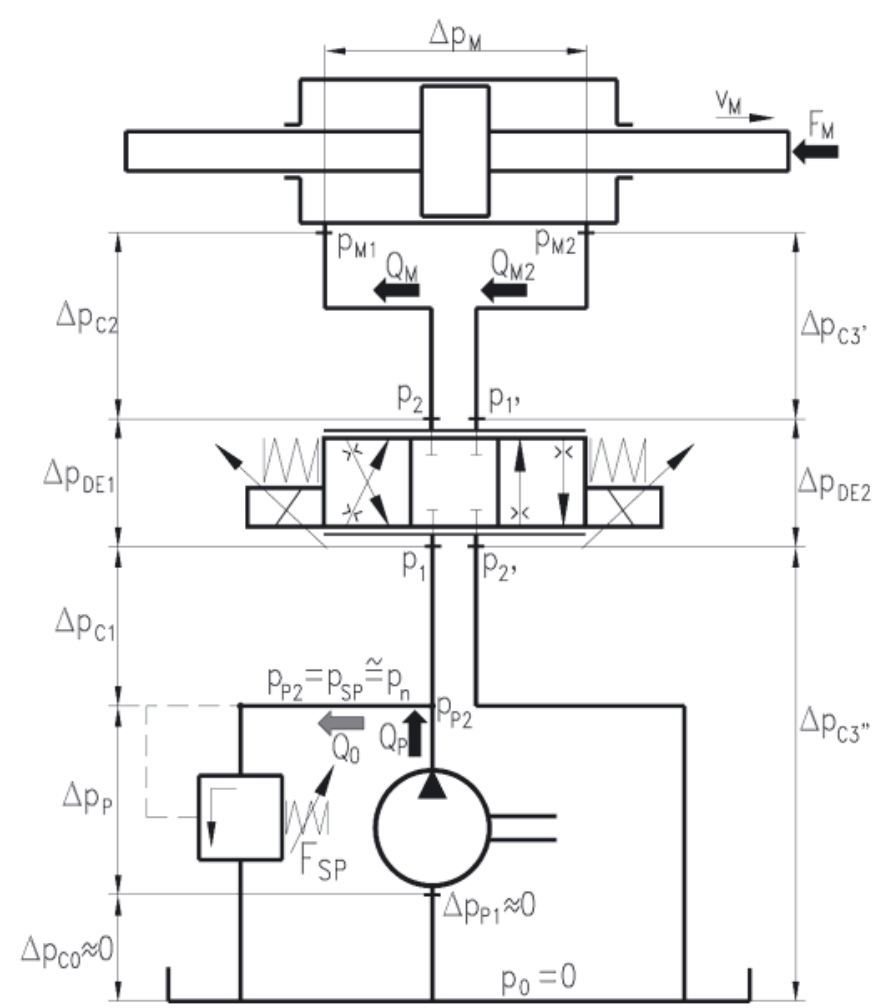

Fig. 1. Diagram of the investigated system fed at constant pressure - a $p=$ cte structure $[1 \div 3]$

The most often used proportional control system of a linear hydraulic motor is a system (Fig. 1), where the proportional directional valve is fed by a constant capacity pump cooperating with an overflow valve stabilizing a constant feed pressure level $(\mathrm{p}=\mathrm{cte})$. Such system achieves high energy efficiency, close to the efficiency of a system without throttling control, only at a point of maximum values of the motor load coefficient $\overline{\mathrm{M}}_{\mathrm{M}}$ and speed coefficient $\bar{\omega}_{\mathrm{M}}$. With decreasing motor load, and particularly with simultaneous decreasing motor speed, the system efficiency $\eta$ decreases rapidly $[1 \div 3]$.

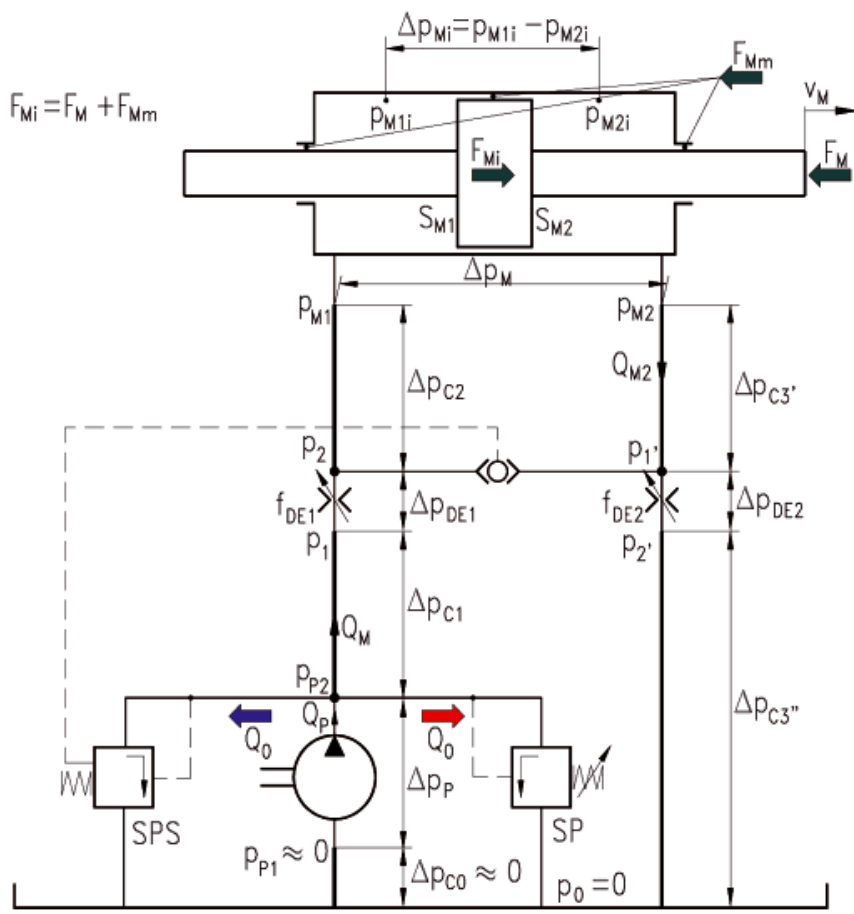

Fig. 2. Diagram of the investigated system with proportional directional valve fed by a constant capacity pump cooperating with an overflow valve controlled in a variable pressure system $-p=\operatorname{var}[1 \div 3]$
There are possibilities of reducing the energy losses in elements (pump, throttling control assembly and hydraulic motor, particularly the linear motor) of a system with proportional control, i.e. possibilities of increasing the energy efficiency of a system with throttling valve.

The hydrostatic system of drive and linear hydraulic motor proportional control may be fed by a constant capacity pump cooperating with an overflow valve stabilizing the proportional directional valve feed pressure at the nominal pressure level (Fig. 1), or by a pump cooperating with an overflow valve controlled by the receiver inlet pressure. The variable pressure $(\mathrm{p}=$ var) (Fig. 2) system makes it possible to reduce losses in the pump, in the control assembly and in the linear hydraulic motor $[1 \div 3]$.

In a variable pressure $(\mathrm{p}=$ var) system, the structural pressure and volumetric losses in the throttling control assembly, mechanical losses in the cylinder and pump as well as volumetric losses in the pump can be significantly reduced. The mathematical description of losses and efficiency is presented in reference [1].

The hydrostatic system structure has an essential influence on the system efficiency. Its impact is most often considered with the assumption of an ideal pump and motor and also with supposition that energy losses in the real pump and motor will cause further proportional decrease of the system overall efficiency. However, the picture of mutual impact of losses in all the hydrostatic system elements appears much more complex [8].

\section{IMPORTANCE OF THE INVESTIGATIONS}

Problems connected with energy efficiency are of basic importance for improvement of functionality and quality of the hydrostatic drive systems, characterised by unquestioned advantages but also by relatively low efficiency in comparison with other types of drive. Publications describing the influence of particular design and operating parameters on the hydrostatic system efficiency are valuable. They make it possible to work out system configurations with losses reduced to a minimum.

Energy efficiency of hydrostatic transmissions, particularly those with throttling control of the motor speed, and also efficiency of the hydraulic servo-mechanism systems may be in fact higher than the values most often quoted in publications on the subject. Possibility of calculating the real value of the hydraulic system overall efficiency as a function of many parameters influencing it, becomes a tool of complete evaluation of the designed system quality. The capability of making such evaluation is important because the hydrostatic control systems are used in various machines and equipment, and also due to increasing power of the hydrostatic drive at the time of constantly increasing costs of energy generation [8].

In a system with too low efficiency, the load, first of all of the pump, increases, which leads to increased risk of failure and the necessary repair or replacement, as well as to a shorter service life. The too low system efficiency, most often resulting from intensive throttling of the stream of liquid, is also a source of rapid deterioration of operational characteristics, particularly the hydraulic oil lubricating properties, which is an effect, among other reasons, of too high temperature of the working liquid - the hydrostatic transmission power medium.

Comparison of power losses in the elements provides information facilitating design of a new system.

Comparison of energy balances from the point of view of the power of losses in different systems gives a broader view for choosing an optimum solution. 


\section{COMPARISON OF THE ENERGY EFFICIENCY OF VARIOUS SYSTEM VERSIONS}

Investigations of the efficiency of elements and systems, taking into account detail analysis of the sources of particular energy losses, may be included in the basic scope of research into the hydrostatic drive and control systems.

The energy efficiency, one of the most important system characteristics, is defined as the ratio of, by the driven device currently demanded, useful power $\mathrm{P}_{\mathrm{Mu}}$ of the hydraulic motor to the power $\mathrm{P}_{\mathrm{Pc}}$, corresponding to $\mathrm{P}_{\mathrm{Mu}}$, obtained by the pump on its shaft from the (electric or combustion) motor driving the pump. In case of improper choice of the system type, the consequence may be increased hydraulic oil temperature, i.e. decreased oil viscosity and, in turn, lower efficiency of the system elements, and also an impact on the system run characteristics. Therefore, the energy efficiency may be a decisive factor for usability of a system in a specific case. But its detailed analysis quite often leads to design improvements of the system elements. However, improving the quality of hydrostatic systems does not consist exclusively in the improvements of their elements [1].

Figures 3 and 4 present the overall efficiency $\eta$ of a constant pressure $(p=c t e)$ and a variable pressure $(p=$ var $)$ system with proportional control and a system with volumetric control by a variable capacity pump $\left(Q_{P}=\right.$ var $)$ as a function of the load coefficient $\overline{\mathrm{M}}_{\mathrm{M}}$ at different values of the cylinder speed coefficient $\bar{\omega}_{\mathrm{M}}$.

In the case of a system with volumetric control by a variable capacity pump $\left(Q_{\mathrm{P}}=\right.$ var $)$, increasing the cylinder load coefficient $\overline{\mathrm{M}}_{\mathrm{M}}$ causes rapid increase of the system overall efficiency $\eta$ (Fig. 3). However, efficiency of structures with the series throttling control fed by a constant capacity pump is, with small value of the $\bar{\omega}_{\mathrm{M}}$ coefficient, distinctly lower than the volumetric control efficiency with the same value of $\bar{\omega}_{\mathrm{M}}$, because the structural losses are high.

Increase of the cylinder speed causes a proportional increase of efficiency of the $p=$ cte and $p=$ var systems, but with an increase of the cylinder speed $v_{M}$ the relative increase of efficiency of the system fed by a variable capacity pump is smaller (Fig. 3).

The overall efficiency $\eta$

of a constant pressure $(p=c t e)$ and a variable pressure $(p=v a r)$ system and a system with volumetric control $\left(Q_{p}=v a r\right)$ - determined by simulation from experimentally obtained $k_{i}$ coefficients

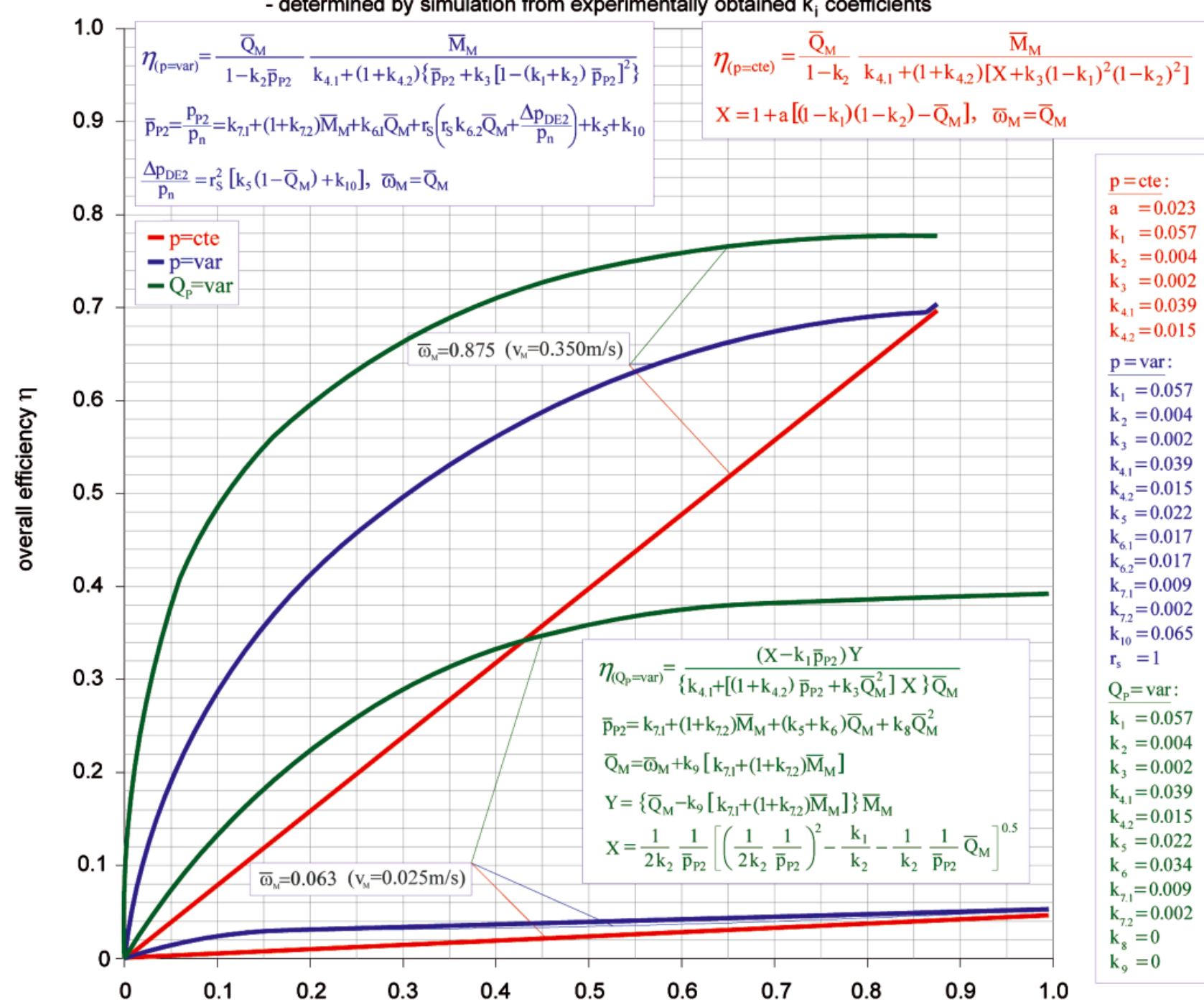

load coefficient $\overline{\mathrm{M}}_{\mathbf{M}}$

Fig. 3. Relation of the overall efficiency $\eta$ of a constant pressure $(p=$ cte) and a variable pressure $(p=v a r)$ system with proportional control and a system with volumetric control by a variable capacity pump $\left(Q_{P}=\right.$ var) to the load coefficient $\bar{M}_{M}$ at different values of the cylinder speed coefficient $\bar{\omega}_{M}$ (efficiency determined by simulation from experimentally obtained $k_{i}$ coefficients; the $v_{M}=0.350 \mathrm{~m} / \mathrm{s}\left(\bar{\omega}_{M}=0.875\right)$ speed was the highest cylinder speed used during the tests) [1] 
The overall efficiency $\eta$

of a constant pressure ( $p=c t e)$ and a variable pressure $(p=v a r)$ system coefficient $k_{10}=0.065$ and 0.010

and a system with volumetric control by a variable capacity pump $\left(Q_{p}=v a r\right)$

- determined by simulation

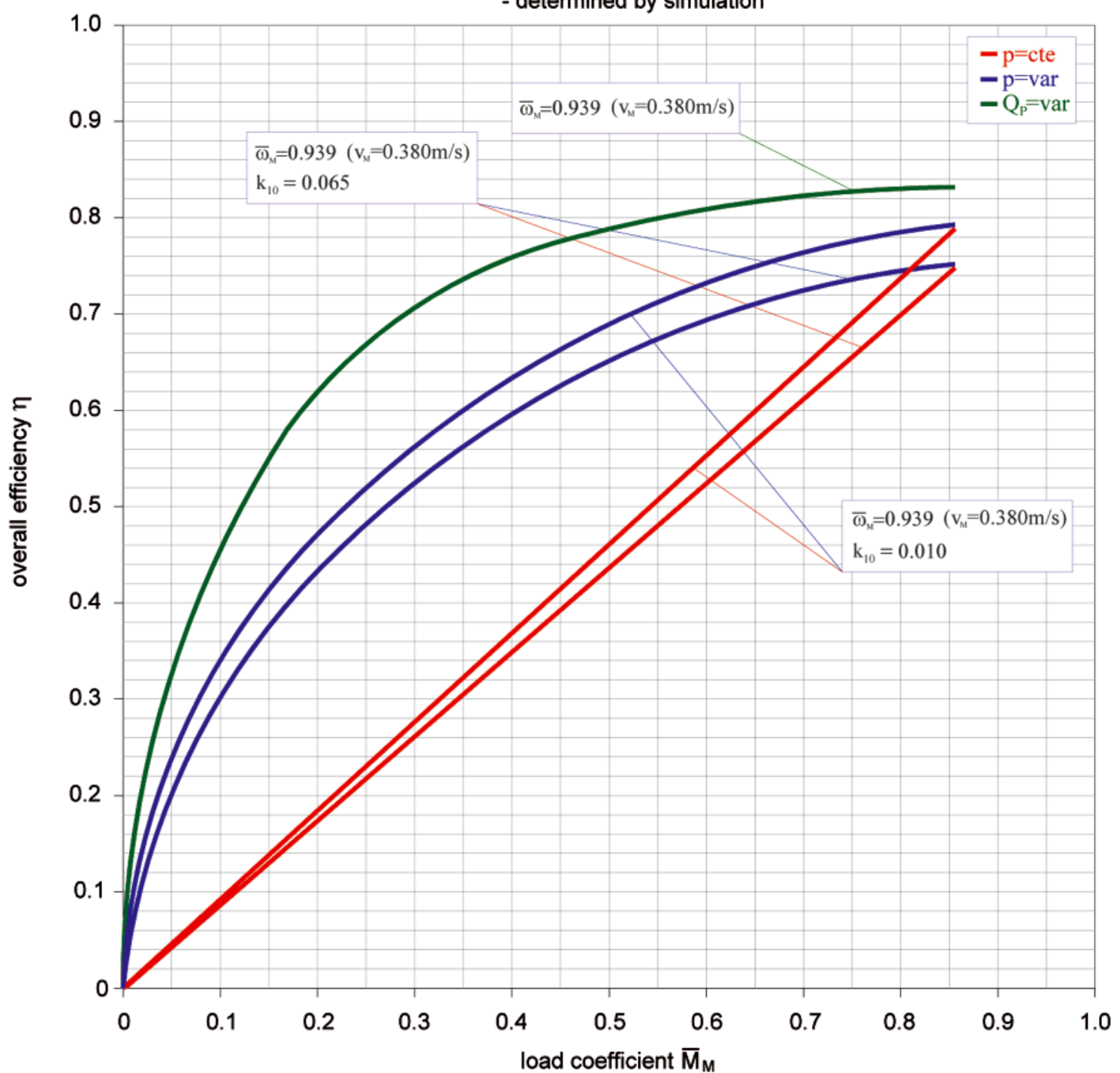

Fig. 4. Relation of the overall efficiency $\eta$ of a constant pressure $(p=$ cte) and a variable pressure $(p=$ var) system with proportional control, with the used proportional directional valve coefficient $k_{10}=0.065$ and with possible use of a bigger proportional directional valve with $k_{10}=0.010$, as well as a system with volumetric control by a variable capacity pump $\left(Q_{P}=\right.$ var $)$, to the load coefficient $\bar{M}_{M}$ at the value of the cylinder speed coefficient $\bar{\omega}_{M}=0.939$ $\left(v_{M}=0.380 \mathrm{~m} / \mathrm{s}\right)$ resulting from the maximum pump capacity $Q_{P \max }$. Maximum $\eta_{\max }$ values of the three considered systems are closer to one another [1].

It can be seen in Fig. 3 that a 14 -fold increase of the cylinder speed in the investigated structures causes about 14-fold increase of their efficiency. As a comparison, a 14-fold increase of the cylinder speed in a $Q_{P}=$ var structure causes about 2-fold increase of its efficiency (from $\eta=0.39$ at $\bar{\omega}_{\mathrm{M}}=0.063$ and $\overline{\mathrm{M}}_{\mathrm{M}}=0.875$ to $\eta=0.78$ at $\bar{\omega}_{\mathrm{M}}=0.875$ and $\left.\overline{\mathrm{M}}_{\mathrm{M}}=0.875\right)$.

Fig. 4 presents efficiency $\eta$ of a constant pressure $(p=$ cte $)$ and a variable pressure $(\mathrm{p}=$ var) system with proportional control, with the used proportional directional valve coefficient $\mathrm{k}_{10}=0.065$ and with possible use of a bigger proportional directional valve with $\mathrm{k}_{10}=0.010$, as well as a system with volumetric control by a variable capacity pump $\left(\mathrm{Q}_{\mathrm{P}}=\right.$ var $)$, as a function of the load coefficient $\overline{\mathrm{M}}_{\mathrm{M}}$ at the value of the cylinder speed coefficient $\bar{\omega}_{\mathrm{M}}=0.939\left(\mathrm{v}_{\mathrm{M}}=0.380 \mathrm{~m} / \mathrm{s}\right)$ resulting from the maximum pump capacity $\mathrm{Q}_{\mathrm{Pmax}}$.

In the maximum cylinder speed range, i.e. with the full use of the pump capacity, efficiency values of the $p=$ cte and $p=$ var systems with throttling control become close to the efficiency of the $\mathrm{Q}_{\mathrm{P}}=$ var system with volumetric control.

\section{CONCLUSIONS}

1. The maximum achievable values of efficiency of systems with proportional (i.e. series throttling) control and of a system with volumetric control by a variable capacity pump are approximately similar. The compared systems were assembled of elements with the same $\mathrm{k}_{\mathrm{i}}$ coefficients of energy losses.

2. By applying a variable pressure $(\mathrm{p}=$ var) system, a significant increase of the energy efficiency $\eta$ can be achieved with smaller cylinder loads.

3. With small cylinder speed values, the effect of using a $\mathrm{p}=$ var system is little, mainly due to volumetric losses connected with draining the excess liquid to the tank.

4. Optimization of hydrostatic systems means, among other aspects, a possibility of foreseeing the behaviour of an energy system in various conditions of its operation, as a function of speed and load of the hydraulic motor, working liquid viscosity, losses in the elements and particularly as 
an effect of the system structure. The common acceptance and use of the objective, experimentally verified methods of determining the system energy efficiency, looking at the efficiency of entire combined system, can clarify many misunderstandings, e.g. those pertaining to the problem of maximum efficiency of specific structures. Such as an answer to the question: has a system with flow regulator different efficiency than a system with common throttling valve?

5. The Author intends to carry out further investigations of systems with proportional control, aimed at determining the influence of the working liquid (oil) viscosity on the energy efficiency.

\section{NOMENCLATURE}

cte - constant

$\mathrm{f}_{\mathrm{DE1}} \quad$ - throttling slot at the cylinder inlet

$f_{\text {DE2 }} \quad-$ throttling slot at the cylinder outlet

$\mathrm{F}_{\mathrm{M} 2} \quad-$ hydraulic linear motor (cylinder) load, current force required of a linear motor

$\mathrm{F}_{\mathrm{Mi}} \quad$ - force indicated on the piston of the hydraulic linear motor (cylinder)

$\mathrm{F}_{\mathrm{Mm}}$ - hydraulic linear motor mechanical losses

$\mathrm{F}_{\mathrm{SP}} \quad$ - force of spring in the overflow valve

$\mathrm{k}_{1} \quad$ - coefficient of relative volumetric losses per one shaft revolution of fixed capacity pump

$\mathrm{k}_{2} \quad-\quad$ coefficient of relative decrease in pump rotational speed

$\mathrm{k}_{3} \quad-$ coefficient of relative pressure losses (flow resistance) in internal pump ducts, at theoretical pump delivery $\mathrm{Q}_{\mathrm{pt}}$

$\mathrm{k}_{4.1}-$ coefficient of relative mechanical losses in pump, at $\Delta \mathrm{p}_{\mathrm{Pi}}$ $=0$

$\mathrm{k}_{4.2} \quad$ - coefficient of relative increase of mechanical pump losses, at increase in pressure in pump working chambers

$\mathrm{k}_{5} \quad-$ coefficient of relative pressure losses (flow resistances) in the line joining the pump with throttle control unit, at theoretical pump delivery $\mathrm{Q}_{\mathrm{Pt}}$

$\mathrm{k}_{6.1}-$ coefficient of relative pressure losses (flow resistances) in the line joining the throttle control unit with hydraulic motor, at theoretical pump delivery $\mathrm{Q}_{\mathrm{pt}}$

$\mathrm{k}_{6.2}-$ coefficient of relative pressure losses (flow resistances) in hydraulic motor outlet line, at theoretical pump delivery $\mathrm{Q}_{\mathrm{Pt}}$

$\mathrm{k}_{7.1} \quad$ - coefficient of relative mechanical losses in hydraulic motor - cylinder, at a force $\mathrm{F}_{\mathrm{M}}=0$

$\mathrm{k}_{7.2}-$ coefficient of relative increase of mechanical losses in motor - cylinder, at increase of force $\mathrm{F}_{\mathrm{M}}$

$\mathrm{k}_{8} \quad-\quad$ coefficient of relative pressure losses (flow resistances) in internal ducts of hydraulic motor, at theoretical pump delivery $\mathrm{Q}_{\mathrm{P}_{\mathrm{t}}}$

$\mathrm{k}_{9} \quad$ - coefficient of relative volumetric losses in hydraulic motor

$\mathrm{k}_{10} \quad-$ coefficient of relative minimum pressure decrease in 2-way flow control valve, which still ensures the flow regulation, or coefficient of relative pressure decrease in 3-way flow control valve

$\mathrm{k}_{11} \quad-$ coefficient of relative pressure decrease $\Delta \mathrm{p}_{\mathrm{DE}}$ in directional control valve (servovalve, proportional valve) demanded by a maximum throttling section $\mathrm{f}_{\mathrm{DEmax}}$ for receiving flow intensity equal theoretical pump delivery $\mathrm{Q}_{\mathrm{Pt}}$

$\overline{\mathrm{M}}_{\mathrm{M}}$ - hydraulic motor relative load coefficient $\overline{\mathrm{M}}_{\mathrm{M}}=\mathrm{F}_{\mathrm{M}} / \mathrm{F}_{\mathrm{Mn}}$

$\mathrm{p}_{0} \quad$ - the reference pressure in the oil reservoir

$\mathrm{p}_{1} \quad-$ pressure at the cylinder feed proportional valve inlet

$\mathrm{p}_{2} \quad-$ pressure in the outlet conduit from proportional valve to the cylinder

$\mathrm{p}_{1}$, $\quad-$ pressure in the inlet conduit to the proportional valve from the cylinder

$\mathrm{p}_{2}, \quad-$ pressure in the outlet conduit from proportional valve to the oil reservoir $\mathrm{p}_{\mathrm{n}} \quad-\quad$ nominal (rated) working pressure of hydrostatic transmission (hydraulic system)

$\mathrm{p}_{\mathrm{M} 1} \quad-$ pressure in the inlet conduit to the cylinder

$\mathrm{p}_{\mathrm{M} 2}-$ pressure in the outlet conduit from the cylinder

$\mathrm{p}_{\mathrm{M} 1 \mathrm{i}}-$ pressure in the inlet chamber of the cylinder

$\mathrm{p}_{\mathrm{M} 2 \mathrm{i}}-$ pressure in the cylinder discharge chamber

$\mathrm{p}_{\mathrm{P} 1} \quad$ - pressure in the pump inlet

$\mathrm{p}_{\mathrm{P} 2} \quad-$ pump supplying pressure

$\mathrm{p}_{\mathrm{SP}} \quad-$ operating pressure overflow valve

$\mathrm{p}_{\mathrm{SP} 0} \quad-$ opening pressure overflow valve for $\left(\mathrm{Q}_{0}=0\right)$

$\mathrm{p}_{\mathrm{SPS}}$ - operating pressure overflow valve controlled by the receiver inlet pressure

$\Delta \mathrm{p}_{\mathrm{C} 0}-$ pressure drop in the inlet conduit to the pump

$\Delta \mathrm{p}_{\mathrm{Cl}}-$ pressure drop in the inlet conduit to the control unit

$\Delta \mathrm{p}_{\mathrm{C} 2}-$ pressure drop in the line between the control unit and cylinder

$\Delta \mathrm{p}_{\mathrm{C} 3}$, - pressure drop in the outlet conduit from cylinder to the proportional valve

$\Delta \mathrm{p}_{\mathrm{C} 3},-$ pressure drop in the outlet conduit of the cylinder from the proportional valve

$\Delta \mathrm{p}_{\mathrm{DE} 1}-$ pressure drop in the proportional directional valve throttling slot $\mathrm{f}_{\mathrm{DE} 1}$ (at the cylinder inlet)

$\Delta \mathrm{p}_{\mathrm{DE} 2}-$ pressure drop in the $\mathrm{f}_{\mathrm{DE} 2}$ proportional valve throttling slot (at the cylinder outlet)

$\Delta \mathrm{p}_{\mathrm{M}}-$ decrease of pressure (pressure drop) in hydraulic linear motor (cylinder)

$\Delta \mathrm{p}_{\mathrm{Mi}}-$ pressure drop indicated between inlet and outlet chamber of the cylinder

$\Delta \mathrm{p}_{\mathrm{P}} \quad-$ increase of pressure in the pump

$\Delta \mathrm{p}_{\mathrm{P} p 1}-$ pressure drop in the inlet channel pump (and the distributor, if any)

$\Delta \mathrm{p}_{\mathrm{P} p 2}-$ pressure drop in the pump outlet duct (and the distributor, if there is one)

$\mathrm{Q}_{0} \quad-\quad$ intensity of flow directed through the overflow valve to the oil reservoir

$\mathrm{Q}_{\mathrm{M}} \quad$ - hydraulic linear motor absorbing capacity, intensity of flow to hydraulic linear motor

$\mathrm{Q}_{\mathrm{M} 2} \quad$ - intensity of flow from the hydraulic linear motor (cylinder)

$\mathrm{Q}_{\mathrm{p}} \quad-$ pump delivery

$\eta \quad-$ energy efficiency

$\mathrm{S}_{\mathrm{M} 1}$ - effective area of the hydraulic linear motor piston in its inlet chamber

$\mathrm{S}_{\mathrm{M} 2}$ - effective area of the hydraulic linear motor piston in its outlet chamber

SP - overflow valve

SPS - overflow valve controlled by the receiver inlet pressure

var - variable

$\mathrm{v}_{\mathrm{M}} \quad-$ hydraulic linear motor speed

$\bar{\omega}_{M}$ - hydraulic linear motor speed coefficient - ratio of instantaneous speed to the nominal one of a hydraulic linear motor $-\bar{\omega}_{\mathrm{M}}=\mathrm{v}_{\mathrm{M}} / \mathrm{v}_{\mathrm{Mn}}$

\section{BIBLIOGRAPHY}

1. Skorek G.: Charakterystyki energetyczne uktadu hydraulicznego o sterowaniu proporcjonalnym siłownika zasilanego pompa o stałej wydajności w systemie statego i zmiennego ciśnienia. Doctor dissertation, 2008

2. Skorek G.: Badania laboratoryjne zachowania energetycznego wybranych elementów ukladu hydraulicznego o sterowaniu proporcjonalnym sitownika zasilanego pompa o statej wydajności. XV Ogólnopolska Konferencja NaukowoTechniczna - Cylinder 2005, „Badanie, Konstrukcja i Eksploatacja Układów Hydraulicznych”, 19-21 September 2005

3. Skorek G.: Zachowanie energetyczne uktadów hydraulicznych o sterowaniu proporcjonalnym liniowego silnika hydraulicznego. X Jubileuszowe Seminarium „Napędy i Sterowanie 2004”, Gdańsk, 18 February 2004

4. Paszota Z.: Metoda oceny sprawności energetycznej ukladów z silnikiem hydraulicznym liniowym - siłownikiem. Politechnika 
Gdańska, Wydział Oceanotechniki i Okrętownictwa, Research report No. 611/95, Gdańsk, 1995

5. Paszota Z.: Model strat i sprawności energetycznej uktadu hydraulicznego o sterowaniu proporcjonalnym siłownika zasilanego pompa o statej wydajności w systemie zmiennego ciśnienia. Rozdział w monografii p.t.: "Badanie, konstrukcja, wytwarzanie i eksploatacja układów hydraulicznych" -

Biblioteka „Cylinder” pod redakcją Edwarda Palczaka, Centrum Mechanizacji Górnictwa Komag, 2005

6. Paszota Z.: Energy Saving in a Hydraulic Servomechanism System - Theory and Examples of Laboratory Verification. Brodogradnja, Journal of Naval Architecture and Shipbuilding Industry, Zagreb, June 2007, Volume 58, Number 2

7. Paszota Z.: Hydrauliczny uktad indywidualny z pompa o statej wydajności i ze sterowaniem proporcjonalnym sitownika-model strat i sprawności energetycznej. Materiały VI Seminarium „Napędy i Sterowanie'2000”, Gdańsk 23 - 25.02.2000, Gdańsk: Politechnika Gdańska, 2000

8. Paszota Z.: Podwyższanie sprawności energetycznej kierunkiem rozwoju napędu hydrostatycznego. Hydraulika i Pneumatyka, Zeszyt 5/98, 1998
9. Paszota Z.: Losses and energy efficiency of drive motors and systems. Replacement of the Sankey diagram of power decrease in the direction of power flow by a diagram of power increase opposite to the direction of power flow opens a new perspective of research of drive motors and systems. Polish Maritime Research 1 (77) Vol. 20, 2013

\section{CONTACT WITH THE AUTHOR}

Grzegorz Skorek, Ph.D.

Department of Engineering Sciences Faculty of Marine Engineering, Gdynia Maritime University

Morska 81/87

81-225 Gdynia, POLAND e-mail: grzesko@am.gdynia.pl 